\title{
The association between asthma control, health care costs, and quality of life in France and Spain
}

\author{
Marianne Doz ${ }^{1}$, Christos Chouaid ${ }^{2}$, Laure Com-Ruelle ${ }^{3}$, Eduardo Calvo ${ }^{4}$, Max Brosa ${ }^{5}$, Julien Robert ${ }^{1}$, \\ Laurent Decuypère ${ }^{6}$, Celine Pribil ${ }^{6}$, Alicia Huerta ${ }^{7}$ and Bruno Detournay ${ }^{1 *}$
}

\begin{abstract}
Background: Current asthma management guidelines are based on the level of asthma control. The impact of asthma control on health care resources and quality of life (QoL) is insufficiently studied. EUCOAST study was designed to describe costs and QoL in adult patients according to level of asthma control in France and Spain.

Methods: An observational cost of illness study was conducted simultaneously in both countries among patients age greater or equal to 18 with a diagnosis of asthma for at least 12 months. Patients were recruited prospectively by GPs in 2010 in four waves to avoid a seasonal bias. Health care resources utilization of the three months before the inclusion was collected through physician questionnaires. Asthma control was evaluated using 2009 GINA criteria over a 3-month period. QoL was assessed using EQ-5D-3L ${ }^{\circledR}$.

Results: 2,671 patients (France: 1,154; Spain: 1,517) were enrolled. Asthma was controlled in 40.6\% [95\% Cl: 37.7\% 43.4\%] and 29.9\% [95\% Cl: 27.6\% - 32.3\%] of French and Spanish patients respectively.

For all types of costs, the percentage of patients using health care resources varied significantly according to the level of asthma control. The average cost (euros/3-months/patient) of controlled asthma was €85.4 (SD: 153.5) in France compared with $€ 314.0$ (SD: 2,160.4) for partially controlled asthma and $€ 537.9$ (SD: 2,355.7) for uncontrolled asthma ( $p<0.0001)$. In Spain, the corresponding figures were $€ 152.6$ (SD: 162.1), €241.2 (SD: 266.8), and €556.8 (SD: 762.4). EQ-5D-3L ${ }^{\circledR}$ score was higher $(p<0.0001)$ in patients with controlled asthma compared to partially controlled and uncontrolled asthma in both countries (respectively 0.88; 0.78; 0.63 in France and 0.89; 0.82; 0.69 in Spain).
\end{abstract}

Conclusions: In both countries, patients presenting with uncontrolled asthma had a significantly higher asthma costs and lower scores of Qol compared to the others.

Keywords: Adult asthmatic patients, Asthma guidelines, EQ-5D-3L ${ }^{\circledR}$, Drugs cost, Economic evaluation

\section{Background}

Asthma is a chronic disease with an estimated 300 million affected individuals throughout the world $[1,2]$. In a large French 2006 survey, 10.2\% of a general population sample declared having suffered from asthma at least once in their life time and $6.7 \%$ had asthma at the time of the survey [3]. In Spain, the European Community Respiratory Health Survey (ECRHS-II) showed that the prevalence of asthma was $7 \%$ in some regional populations in 2007 [4].

\footnotetext{
* Correspondence: bruno.detournay@cemka.fr

'Cemka-Eval, 43 Boulevard du Maréchal Joffre, Bourg-la-Reine F-92340, France

Full list of author information is available at the end of the article
}

The recent publication from the Global Initiative for Asthma (GINA) updated international guidelines and highlighted the importance of achieving and maintaining control as a goal of treatment [1,5]. Standardized tools [6-9] have been developed to assess asthma control.

Until now, some studies on asthma control based on data from large samples of asthmatic patients have already been published in Europe [10,11]. However, such studies were based on definitions of control that do not correspond to those of current GINA criteria. Moreover, asthma control was assessed over various periods of time (weeks/months) without taking into account symptoms seasonality [12].

Poor control of asthma may result in adverse clinical outcomes as well as substantial economic costs [13].

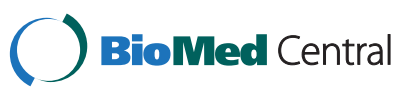


The total cost of asthma was estimated at 1.5 billion euros in France [14] and between 0.9 and 1.2 billion euros in Spain [15]. In 2006, the French ESPS survey estimated that the mean per-patient annual cost of ambulatory care was 1.6 times higher in partially controlled, and 2.9 times higher in uncontrolled asthma as compared to controlled asthma [16] but few European studies have provided data on costs related to asthma control. Finally, uncontrolled asthma may also have a negative impact on patient's quality of life [17]. Data from the ECRHSII showed that in patients with a known diagnosis of asthma, respiratory symptoms are important determinants of reduced health related quality of life (HRQL) [18]. Nevertheless, the specific relation between levels of asthma control and quality of life has been poorly documented [19-21].

Consequently, the EUCOAST (EUropean COst of ASthma Treatment) study was designed to assess utilisation of healthcare resources, costs and HRQL in adult patients with asthma in a real life setting in France and Spain accordingly to the level of asthma control.

\section{Methods}

\section{Study design}

An observational study was conducted in primary care settings in France and Spain in order to estimate the societal costs and the HRQL according to the level of asthma control in adult patients.

The study design required a single visit per patient. Data collection was performed on the three-month period before the inclusion. To take into account seasonality which has a major impact on asthma in both countries [12], patients were recruited during a period of one year in four quarterly waves from $01 / 01 / 2010$ to 12 / $31 / 2010$.

The EUCOAST study was approved by the French Consultative Committee for the data processing in health research (CCTIRS) and by the National commission for the personal data protection (CNIL). In Spain, the study obtained the authorisation of the Spanish Agency of Medicines and Medical Devices (AEMPS) and the favourable opinion of the Clinical research Ethics Committee (CEIC) Hospital Clínico y Provincial de Barcelona.

\section{Populations}

Patients were included if they met the following inclusion criteria: adults aged 18 or over, diagnosed with asthma for at least 12 months and having received at least one anti-asthmatic treatment (whatever the treatment) within the past 12 months.

Exclusion criteria were participation into a clinical trial during the past 6 months, aged 45 years and over with a history of smoking of at least 20 pack years, chronic obstructive pulmonary disease (COPD) or pregnancy.
Based on the percentage of patients with controlled asthma estimated to represent $40 \%$ to $50 \%$ of the overall population in previous studies [22], and knowing that the size of the sample needed to estimate percentage with a $\pm 5 \%$ value according to the confidence interval selected (alpha risk 5\%, normal distribution), around 380 patients had to be enrolled quarterly.

In France, investigators were a sample of GPs selected from a representative panel of 1,200 general practitioners. The panel's representativeness was established by three criteria: age, sex and region of practice. The study was proposed to 750 GPs of this panel, randomly selected and 230 agreed to participate.

In Spain, 105 general practitioners of 18 autonomous communities belonging to 3 regions (North, South and Mediterranean) were contacted and 87 agreed to participate. A territorial representativeness was able to be obtained when the sample was constituted.

Practitioners had to include patients in the usual context of their practice. To avoid a selection bias, the first two consecutive patients (the first five in Spain) corresponding to the inclusion/exclusion criteria visiting their doctor were included in each wave.

\section{Data collection}

Data collected retrospectively (over the last 3 months) during the single study visit by the GP were: sociodemographic characteristics, medical history of patients, GINA criteria (including occurrences of exacerbations, limitations of activities, daytime and nocturnal symptoms, need of rescue/reliever treatment) and healthcare resource use due to asthma.

For all medical resources consumption (including sick leaves) during the 3 months prior to GP visit, data were provided by GPs through the questionnaires used in the study. In France some data (i.e. prescription drugs related to asthma were also collected through the computerized medical files of the GPs).

Force Expiratory Volume in one second (FEV1) was collected only in a single visit (FEV1 was measured by GPs three times consecutively as recommended by GINA). As in France and Spain, all investigators were given a digital device (Mini-Wright ${ }^{\mathrm{TM}}$ Digital, Clement Clarke International Ltd) which allowed FEV1 measurements.

At the time of the inclusion, patients completed the EQ-5D-3L ${ }^{\circledR}$ questionnaire comprising a Visual Analog Scale (VAS). This questionnaire is a generic instrument [23] which comprises 5 dimensions: mobility, self-care, usual activity, pain/discomfort and anxiety/depression and it is widely used to assess HRQL in asthma patients $[24,25]$. EQ-5D-3L ${ }^{\circledR}$ health states were valuated using validated French [26] and Spanish [27] utility value set available in each country. 


\section{Data analysis}

In France, data were weighted to compensate the disproportion of inclusions observed among the different quarterly waves. Individual case weights were defined according to the ratio between the number of inclusions in wave 1 and the number of inclusions in the subsequent waves. In Spain, as the number of inclusions was similar in each wave, it was not necessary to weight the data.

Data analysis was performed for patients for whom lung function and symptoms of asthma were duly collected in the medical questionnaire. According to GINA 2009 criteria, patients were classified in 3 subgroups ("controlled, "partially controlled" and "uncontrolled" patients); statistic tests were performed to compare these 3 subgroups.

For categorical variables (age, gender, co-morbidities, exacerbations, smoking status, FEV1, visits, hospitalization, ambulatory exams, emergency room, drugs, sick leave), Pearson's Chi2 test or Fisher's Exact Test were applied. For continuous variables (costs, EQ-5D-3L ${ }^{\circledR}$ scores, VAS score, and number of years with a diagnosed asthma), analysis of the variance was performed. If the data were not normally distributed, non-parametric tests were used. The cost analysis was carried out according to a societal perspective and took into account both direct and indirect costs (costs associated with sick leave). Considering differences between the Spanish and the French healthcare systems, it was judged as not relevant to compare cost data across the two countries. A unit cost was given to each item according to the tariff currently used in $2010^{\mathrm{a}, \mathrm{b}}$. A weighted average cost was then calculated. In France, accordingly to national guidelines, productivity loss was estimated by using the human capital method. The Gross Domestic Product for the year 2008 was divided by the number of employed population given by the "Institut National de la Statistique et des études économiques" (INSEE) for the same year. Then, the GDP per capita (employed population only) was divided by the number of working days. In Spain the average annual salary was used and sick leaves were valued by using the average annual salary divided by the number of working hours in a year (provided in Instituto Nacional de Estadística). In both case, results were multiplied by the duration of sick leaves collected through the survey.

As data were collected on a 3-month period, cost data were not discounted.

Multivariate regression analyses were performed to examine the relation between level of asthma control and the outcomes (direct costs only or HRQL levels). The costs or HRQL levels were the dependent variable and control level was the independent (explanatory) variable.

The Tobit model was used for the relation between cost and level of asthma control in order to take into account patients with zero costs (i.e., left-censoring of cost data). Multiple linear regression was used to estimate the effect associated with level of control on HRQL. The potentially confounding factors taken into account in the models were sex, age, episodes of exacerbation of asthma, prescription of a controller treatment and follow-up by a lung specialist.

\section{Results}

\section{Study population}

Two hundred thirty-eight investigators (155 in France and 83 in Spain) enrolled 2,671 patients (1,154 in France and 1,517 in Spain), Data on FEV1 or asthma symptoms were missing for 26 patients in France and 31 in Spain), and data on HRQL were missing for 310 patients in France and 51 in Spain (Figure 1). Table 1 presents characteristics of the study population by country and according to the level of control.

\section{France}

Asthma was considered as controlled over the last 3 months in $40.6 \%$ [95\% CI: $37.7 \%$ - 43.4\%], partially controlled in $38.0 \%$ [95\% CI: $35.2 \%-40.8 \%$ ] and uncontrolled in $21.4 \%$ [95\% CI: $19.1 \%-23.8 \%$ ] of patients.

Among patients with an uncontrolled asthma a higher percentage of women $(66.1 \%$ for $v s .62 .2 \%$ for partially controlled vs. $54.9 \%$ for controlled, $\mathrm{p}<0.0001$ ) and patients aged 65 and over $(28.2 \%$ vs. $20.7 \%$ for partially controlled vs. $17.6 \%$ for controlled, $\mathrm{p}<0.0001)$ were observed.

Those with uncontrolled asthma had a higher rate of depression $(\mathrm{p}<0.0001)$ than patients with partially controlled or controlled asthma. Prevalence of allergic rhinitis, atopic dermatitis, or gastroesophageal reflux was not significantly related to asthma control.

Asthma exacerbations occurred for $34.6 \%$ of patients during the last 3 months with an average number of 2.3 (SD: 3.0) episodes/patient with exacerbations/quarter. As expected, the percentage of patients who had at least one exacerbation was significantly higher $(\mathrm{p}<0.0001)$ in patients with uncontrolled asthma (62.8\%) compare to partially controlled patients $(36.2 \%)$ and controlled patients (18.5\%). Overall, $70.4 \%$ of patients had a normal lung function (FEV1 $\geq 80 \%$ ): $84.8 \%$ of those with controlled asthma $v s .67 .8 \%$ for partially controlled and $57.2 \%$ for uncontrolled asthma $(\mathrm{p}<0.0001)$.

\section{Spain}

The proportion of patients with controlled, partially controlled and uncontrolled asthma were 29.9\% [95\% CI: $27.6 \%$ - 32.3\%], 34.1\% [95\% CI: $31.6 \%$ - 36.5\%] and 36.0\% [95\% CI: 33.6\%-38.5\%], respectively. The level of asthma control was lower in Spain than in France 


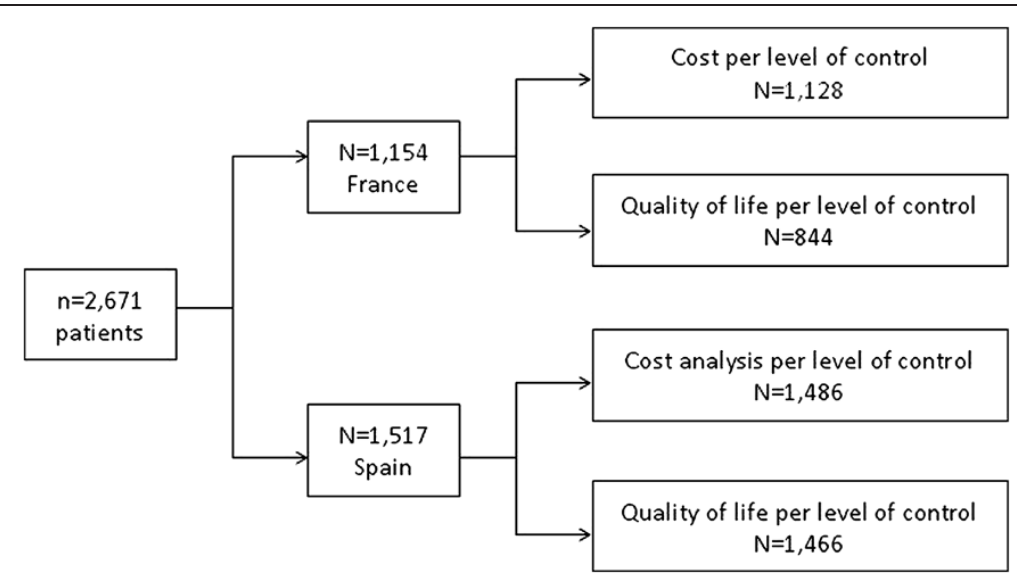

Figure 1 Study populations of analyses.

$(\mathrm{p}<0.001)$. Patients with controlled asthma were younger than patients with uncontrolled asthma $(\mathrm{p}<0.0001)$.

There was a significant relation between asthma control and rate of allergic rhinitis, atopic dermatitis, and gastroesophageal reflux as well as depression with more frequent comorbidities in patients with uncontrolled asthma. $43.6 \%$ of patients suffered from asthma exacerbations during the last 3 months with an average number of 1.8 (SD1.7) episodes/patient with exacerbations/ quarter: $74.4 \%$ of those with uncontrolled asthma, $41.3 \%$ with partially controlled and $9.2 \%$ with controlled asthma.

Overall, 78.7\% of patients had a normal lung function (90.7\% of those with controlled vs. $74.4 \%$ with partially controlled vs. $72.0 \%$ with uncontrolled asthma).

\section{Health resources consumptions and cost of asthma France}

Detailed analyses showed that, for all types of costs, the percentage of patients with medical resource consumption varied significantly according to the level of asthma control (Table 2).

The average per-patient total cost of asthma-related healthcare was $€ 537.9$ in uncontrolled patients, $€ 314.0$ in partially controlled patients and $€ 85.4$ in controlled patients $(\mathrm{p}<0.0001)$. Antiasthmatic drugs represented the main driver of direct costs, $86.2 \%, 81.9 \%$ and $61.5 \%$ in controlled, partially controlled and uncontrolled patients, respectively.

Indirect costs were marginal in controlled patients (4.9\% of the total costs) but represented a major driver in partially controlled and uncontrolled patients (respectively $62.8 \%$ and $58.1 \%$ ) (Table 3 ).

The multivariate analysis showed that total direct costs over 3 months were higher in patients with uncontrolled asthma rather than in patients with controlled asthma (+ $€ 112.8$ in uncontrolled patients $v s$. controlled), older people $(\geq 65)$ rather than younger ones patients $(+€ 49$.), experiencing exacerbations $(+€ 75.5)$, treated with controller treatment $(+€ 253.7$, or visiting a lung specialist $(+$ $€ 62.4$ ), (Table 4). Such figures must be interpreted with caution due to the fact that the level of control may be the consequence of other covariables (i.e. the controller treatment).

\section{Spain}

The mean per-patient total cost of asthma-related healthcare was $€ 556.8$ in uncontrolled patients, $€ 241.2$ in partially controlled patients and $€ 152.6$ in controlled patients $(\mathrm{p}<0.0001)$ (Table 3). $92.9 \%$ of patients with uncontrolled, as compared with $78.4 \%$ of patients with controlled asthma, were prescribed at least one antiasthmatic drugs during the observation period $(\mathrm{p}<0.05)$ (Table 2$)$.

Antiasthmatic medications represented the main driver of direct costs for controlled and partially controlled asthma (respectively 59.0\% and 52.7\%) but not for uncontrolled asthma (36.5\%). For the latter GPs visits had also a major impact on costs accounting for $32.9 \%$ of the mean per-patient direct costs.

Indirect costs were marginal in controlled and in partially controlled patients (respectively $2.6 \%$ and $4.7 \%$ of the total costs) but much more important $(22 \%)$ in uncontrolled patients.

In multivariable analyses, factors predicting asthma costs were the same in both countries except for gender which had a significant impact in Spain but not in France (Table 4).

\section{Quality of life in France and Spain}

In both countries (Table 5), average EQ-5D-3L ${ }^{\circledR}$ quality of life scores were higher for patients with controlled asthma than patients with partially controlled or uncontrolled asthma ( 0.88 vs. 0.78 vs. 0.63 in France and 0.89 vs. 0.82 vs. 0.69 in Spain; $\mathrm{p}<0.0001)$. 
Table 1 Characteristics of the asthmatic population in France and Spain according to the level of control

\begin{tabular}{|c|c|c|c|c|c|c|c|c|}
\hline \multirow{2}{*}{$\begin{array}{l}\text { Over a 3-month } \\
\text { period } \\
\text { Level of asthma } \\
\text { control }\end{array}$} & \multicolumn{4}{|c|}{ France $1,154(100 \%)$} & \multicolumn{4}{|c|}{ Spain 1,517 (100\%) } \\
\hline & $\begin{array}{c}\text { Controlled } \\
458(40.6 \%)\end{array}$ & $\begin{array}{c}\text { Partially } \\
\text { controlled } 428 \\
(38.0 \%) \\
\end{array}$ & $\begin{array}{l}\text { Uncontrolled } \\
242(21.4 \%)\end{array}$ & $p$ & $\begin{array}{l}\text { Controlled } \\
445(29.9 \%)\end{array}$ & $\begin{array}{c}\text { Partially } \\
\text { controlled } 506 \\
(34.1 \%) \\
\end{array}$ & $\begin{array}{l}\text { Uncontrolled } \\
535(36.0 \%)\end{array}$ & $p$ \\
\hline Gender & & & & 0.008 & & & & 0.3337 \\
\hline Male & $45.1 \%$ & $37.8 \%$ & $33.9 \%$ & & $38.7 \%$ & $37.2 \%$ & $34.2 \%$ & \\
\hline Female & $54.9 \%$ & $62.2 \%$ & $66.1 \%$ & & $61.3 \%$ & $62.8 \%$ & $65.8 \%$ & \\
\hline Age & & & & 0.0132 & & & & $<0.0001$ \\
\hline$[18-45[$ & $40.2 \%$ & $42.7 \%$ & $35.6 \%$ & & $60.3 \%$ & $52.2 \%$ & $44.8 \%$ & \\
\hline$[45-65[$ & $42.2 \%$ & $36.5 \%$ & $36.3 \%$ & & $27.7 \%$ & $25.9 \%$ & $35.3 \%$ & \\
\hline$\geq 65$ & $17.6 \%$ & $20.7 \%$ & $28.2 \%$ & & $12.0 \%$ & $21.9 \%$ & $19.9 \%$ & \\
\hline Mean (SD) & $48.4(16.6)$ & $49.0(18.0)$ & $53.3(18.3)$ & 0.0013 & $42.4(15.9)$ & $45.6(19.0)$ & $47.8(17.7)$ & $<0.0001$ \\
\hline \multicolumn{9}{|l|}{$\begin{array}{l}\text { Number of years with a } \\
\text { diagnosed asthma }\end{array}$} \\
\hline Mean (SD) & $17.8(13.7)$ & $19.1(14.1)$ & $20.9(14.6)$ & 0.0234 & $13.2(10.5)$ & $13.7(10.4)$ & $15.8(11.7)$ & 0.0004 \\
\hline $\begin{array}{c}\text { Comorbidities (at least } \\
\text { one) }\end{array}$ & $68.8 \%$ & $73.1 \%$ & $79.0 \%$ & 0.0154 & $72.1 \%$ & $76.5 \%$ & $83.1 \%$ & 0.0002 \\
\hline Allergic rhinitis & $70.2 \%$ & $68.8 \%$ & $62.4 \%$ & 0.1668 & $81.0 \%$ & $77.0 \%$ & $70.9 \%$ & 0.0047 \\
\hline Atopic dermatitis & $13.6 \%$ & $14.2 \%$ & $19.2 \%$ & 0.1983 & $17.4 \%$ & $18.9 \%$ & $24.5 \%$ & 0.0325 \\
\hline Others allergies & $15.1 \%$ & $16.3 \%$ & $12.0 \%$ & 0.4036 & $12.3 \%$ & $11.1 \%$ & $13.3 \%$ & 0.6355 \\
\hline GERD $\mp$ & $18.9 \%$ & $24.6 \%$ & $25.9 \%$ & 0.1099 & $12.3 \%$ & $9.8 \%$ & $19.4 \%$ & 0.0002 \\
\hline Depression & $12.3 \%$ & $17.8 \%$ & $30.0 \%$ & $<0.0001$ & $7.9 \%$ & $12.7 \%$ & $16.7 \%$ & 0.0017 \\
\hline $\begin{array}{c}\text { Another disease related } \\
\text { to asthma }\end{array}$ & $6.5 \%$ & $10.0 \%$ & $13.0 \%$ & 0.0453 & $8.7 \%$ & $11.1 \%$ & $9.0 \%$ & 0.4783 \\
\hline $\begin{array}{l}\text { Asthma exacerbations } \\
\text { (last } 3 \text { months) Yes }\end{array}$ & $18.5 \%$ & $36.2 \%$ & $62.8 \%$ & $<0.0001$ & $9.2 \%$ & $41.3 \%$ & $74.4 \%$ & $<0.0001$ \\
\hline Smoking status & & & & 0.1076 & & & & 0.0461 \\
\hline Current smoker & $14.0 \%$ & $20.0 \%$ & $18.7 \%$ & & $13.0 \%$ & $16.7 \%$ & $18.8 \%$ & \\
\hline Former smoker & $17.6 \%$ & $13.6 \%$ & $15.4 \%$ & & $18.0 \%$ & $12.9 \%$ & $15.4 \%$ & \\
\hline Never smoker & $68.4 \%$ & $66.4 \%$ & $65.9 \%$ & & $69.0 \%$ & $70.4 \%$ & $65.9 \%$ & \\
\hline 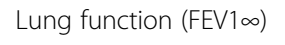 & & & & $<0.0001$ & & & & $<0.0001$ \\
\hline$<50 \%$ & $4.7 \%$ & $8.3 \%$ & $15.5 \%$ & & $0.9 \%$ & $5.0 \%$ & $5.8 \%$ & \\
\hline $50-79 \%$ & $10.6 \%$ & $23.9 \%$ & $27.3 \%$ & & $8.4 \%$ & $20.7 \%$ & $22.1 \%$ & \\
\hline$\geq 80 \%$ & $84.8 \%$ & $67.8 \%$ & $57.2 \%$ & & $90.7 \%$ & $74.4 \%$ & $72.0 \%$ & \\
\hline
\end{tabular}

₹ Gastroesophageal reflux disease.

$\infty$ Forced expiratory volume in one second.

Detailed analyses of EQ-5D-3L ${ }^{\circledR}$ results per dimension (mobility, autonomy, daily activities, pain/discomfort, and anxiety/depression) showed consistent differences between controlled, partially controlled and uncontrolled patients. For all dimensions, quality of life scores were better for controlled patients $(\mathrm{p}<0.0001)$ (data not shown).

The Visual Analog Scale (VAS) quality of life scores were also significantly associated with the level of asthma control in both countries (p-values < 0.001). Average VAS scores were 77.33, 70.27, 57.41 in France and 80.00, 75.13, 62.81 in Spain for controlled, partially controlled and uncontrolled patients, respectively (Table 5)

In France, using multi-variable regression analyses, the EQ-5D-3L ${ }^{\circledR}$ scores (Table 6) were significantly lower for patients having an uncontrolled (estimated value -0.22) or partially controlled asthma (estimated value -0.09) as compared with controlled asthma. They were also lower for female patients and patients aged 65 years or more (estimated value -0.13) or 45-64 (estimated value -0.07) rather than those aged 18-44 years.

Similar results were observed in Spain. In addition, in that country, follow-up by a pulmonary specialist was 
Table 2 Asthma associated consumption of medical resources within the last 3 months according to the level of control

\begin{tabular}{|c|c|c|c|c|c|c|c|c|}
\hline \multirow{3}{*}{$\begin{array}{l}\text { Over a 3-month period } \\
\text { Asthma control }\end{array}$} & \multicolumn{4}{|c|}{ France $1,154(100.0 \%)$} & \multicolumn{4}{|c|}{ Spain 1,517 (100.0\%) } \\
\hline & $\begin{array}{c}\text { Controlled } \\
458(40.6 \%)\end{array}$ & $\begin{array}{c}\text { Partially } \\
\text { controlled } 428 \\
(38.0 \%)\end{array}$ & $\begin{array}{l}\text { Uncontrolled } \\
242(21.4 \%)\end{array}$ & & $\begin{array}{l}\text { Controlled } \\
445(29.9 \%)\end{array}$ & $\begin{array}{c}\text { Partially } \\
\text { controlled } 506 \\
(34.1 \%)\end{array}$ & $\begin{array}{l}\text { Uncontrolled } \\
535(36.0 \%)\end{array}$ & \\
\hline & $\%$ & $\%$ & $\%$ & $\mathrm{p}$ & $\%$ & $\%$ & $\%$ & $\mathrm{p}$ \\
\hline $\begin{array}{l}\text { At least one prescription } \\
\text { of antiasthmatic drugs }\end{array}$ & 57.9 & 67.3 & 71.7 & 0.0004 & 78.4 & 87.7 & 92.9 & $<0.0001$ \\
\hline Reliever treatment only & 6.9 & 6.8 & 5.9 & 0.8583 & 18.2 & 16.2 & 10.8 & 0.0032 \\
\hline $\begin{array}{c}\text { Controller or Reliever and } \\
\text { controller treatment }\end{array}$ & 51 & 60.5 & 65.8 & 0.0003 & 60.2 & 71.5 & 82.1 & $<0.0001$ \\
\hline At least one GP Visit & 35.4 & 44.5 & 70.0 & $<0.0001$ & 47.2 & 64.2 & 81.9 & $<0.0001$ \\
\hline $\begin{array}{l}\text { At least one specialist } \\
\text { visit }\end{array}$ & 2.1 & 5.1 & 15.7 & $<0.0001$ & 11.2 & 13.8 & 22.2 & $<0.0001$ \\
\hline $\begin{array}{l}\text { At least one } \\
\text { physiotherapist visit }\end{array}$ & 0.2 & 0.3 & 3.1 & $<0.0001$ & 1.1 & 1.2 & 4.3 & 0.0005 \\
\hline At least one nurse visit & 0.2 & 0.4 & 3.1 & $<0.0001$ & 5.8 & 9.7 & 17.8 & $<0.0001$ \\
\hline $\begin{array}{l}\text { At least one emergency } \\
\text { room visit }\end{array}$ & 0 & 0.7 & 3.6 & $<.0001$ & 0.7 & 2.4 & 14.4 & $<0.0001$ \\
\hline $\begin{array}{l}\text { At least one } \\
\text { hospitalization }\end{array}$ & 0 & 0 & 2.1 & NA & 0 & 1.0 & 7.3 & $<0.0001$ \\
\hline $\begin{array}{l}\text { At least one ambulatory } \\
\text { exam }\end{array}$ & 2.1 & 5.6 & 9.7 & $<0.0001$ & 27.0 & 27.5 & 38.3 & $<0.0001$ \\
\hline At least one sick leave & 0.5 & 2.1 & 5.3 & 0.0002 & 0.7 & 1.6 & 13.9 & $<0.0001$ \\
\hline
\end{tabular}

NA Not applicable.

also significantly associated with a decrease in quality of life (estimated value $-0.06 ; \mathrm{p}<0.0003$ ).

Results of the multivariable analysis using the VAS score as the dependent variable were consistent with those reported above for the EQ-5D-3L ${ }^{\circledR}$. In addition, exacerbations were significantly associated with a lower VAS score in both countries.

\section{Discussion}

In this observational study we found that the proportion of patients with controlled asthma was significantly higher in France (41\%) than in Spain (30\%). In both countries, costs were higher and HRQL lower as level of asthma control decreased. The average asthma-related total health care costs over a three-month period were $€ 85.4, € 314.4$ and $€ 537.9$ in France and $€ 152.6, € 241.2$ and $€ 556.8$ in Spain for patients with controlled, partially controlled and uncontrolled asthma, respectively. The HRQL scores (EQ-5D-3L ${ }^{\circledR}$ ) were $0.88,0.78$ and 0.63 in France $(p<0.0001)$ and $0.89,0.82$ and $0.69(p<0.0001)$ in Spain, for patients with controlled, partially controlled and uncontrolled asthma, respectively. According to the GINA 2009 Guidelines [1], the goal of asthma treatment is to achieve and maintain asthma control. The level of control is assessed based on symptoms, the use of reliever treatments, the adaptation of daily life, and measurement of peak expiratory flow or FEV1. However, this assessment of the level of asthma control may be conducted in different ways and the level of control can also vary over time.

The GINA 2009 criteria did not specify precisely the period over which asthma control should be assessed. Instead, any of the criteria observed over a given week may affect the level of asthma control for the whole period. Recently, for the first time, GINA 2010 [28] guidelines provided a time frame for the assessment of asthma control and recommended that asthma control must be assessed "preferably over 4 weeks". In our study, asthma control was assessed using symptoms data on a three-month period but FEV1 was measured only at the end of that period of time and this may be considered as a limitation of our study.

Previous studies estimated that approximately $40 \%$ of patients in France [29] have uncontrolled asthma. Similar figures were observed in Spain [30]. These estimates are higher than those in our study in France (uncontrolled asthma $=21.4 \%$ ) but consistent with our results in Spain (uncontrolled asthma $=36 \%$ ). However, the differences between our results and previous ones may be the consequence of slightly different definitions of asthma control. The reasons for the differences in asthma control between the two neighbouring countries are not 
Table 3 Mean per-patient asthma-related total cost (euros), societal perspective, according to the level of control GINA (last 3 months)

\begin{tabular}{|c|c|c|c|c|c|c|c|c|}
\hline \multirow{3}{*}{ Asthma control } & \multicolumn{4}{|c|}{ Societal perspective, France } & \multicolumn{4}{|c|}{ Societal perspective, Spain } \\
\hline & $\begin{array}{c}\text { Controlled } \\
\mathrm{N}=458\end{array}$ & $\begin{array}{c}\text { Partially } \\
\text { controlled } \mathrm{N}=428\end{array}$ & $\begin{array}{l}\text { Uncontrolled } \\
\mathrm{N}=242\end{array}$ & & $\begin{array}{c}\text { Controlled } \\
\mathrm{N}=445\end{array}$ & $\begin{array}{c}\text { Partially } \\
\text { controlled } \mathrm{N}=506\end{array}$ & $\begin{array}{l}\text { Uncontrolled } \\
\mathrm{N}=535\end{array}$ & \\
\hline & Mean (sd) & Mean (sd) & Mean (sd) & $\mathbf{p}^{*}$ & Mean (sd) & Mean (sd) & Mean (sd) & $\mathbf{p}^{*}$ \\
\hline $\begin{array}{l}\text { Antiasthmatic } \\
\text { drugs }(€)\end{array}$ & $70.0(108.3)$ & $95.7(141.2)$ & $138.6(231.4)$ & $<0.0001$ & $87.7(103.9)$ & $121.1(121.2)$ & $158.4(141.3)$ & $<0.0001$ \\
\hline $\begin{array}{l}\text { Reliever treatment } \\
\text { only }\end{array}$ & $4.5(16.6)$ & $8.4(25.3)$ & $16.4(49.4)$ & $<0.0001$ & $3.6(13.8)$ & $5.6(21.8)$ & $13.4(37.3)$ & $<0.0001$ \\
\hline Controller treatment & $23.0(61.5)$ & $32.3(68.6)$ & $50.0(112.0)$ & 0.0011 & $24.6(60.1)$ & $32.5(65.1)$ & $41.6(67.9)$ & $<0.0001$ \\
\hline Fixed association & $42.5(78.4)$ & $55.0(97.1)$ & $72.2(118.8)$ & 0.0005 & $59.5(77.6)$ & $83.0(88.4)$ & $103.4(95.9)$ & $<0.0001$ \\
\hline GP Visits $(€)$ & $9.7(15.6)$ & $15.8(26.2)$ & $36.4(50.6)$ & $<0.0001$ & $35.3(57.7)$ & $71.4(90.1)$ & $142.9(148.8)$ & $<0.0001$ \\
\hline Specialist visits & $0.5(3.6)$ & $2.0(10.2)$ & $5.7(14.8)$ & $<0.0001$ & $7.5(22.4)$ & $12.2(37.5)$ & $23.0(56.8)$ & $<0.0001$ \\
\hline $\begin{array}{l}\text { Physiotherapist } \\
\text { visits }(€)\end{array}$ & $0.0(0.6)$ & $0.1(1.3)$ & $2.5(19.8)$ & $<0.0001$ & $0.3(2.8)$ & $0.2(2.2)$ & $1.0(5.5)$ & 0.0005 \\
\hline Nurse visits (€) & $0.0(0.2)$ & $0.0(0.5)$ & $0.5(4.5)$ & $<0.0001$ & $1.9(9.8)$ & $3.2(12.2)$ & $7.7(22.5)$ & $<0.0001$ \\
\hline $\begin{array}{l}\text { Emergency } \\
\operatorname{room}(€)\end{array}$ & $0.0(-)$ & $0.9(11.5)$ & $4.0(22.1)$ & $<0.0001$ & $0.9(11.3)$ & $4.1(29.2)$ & $25.3(69.2)$ & $<0.0001$ \\
\hline Hospitalization $(€)$ & $0.0(-)$ & $0.0(-)$ & $33.6(227.1)$ & $<0.0001$ & $0.0(-)$ & $3.9(44.6)$ & $55.3(268.5)$ & $<0.0001$ \\
\hline $\begin{array}{l}\text { Ambulatory } \\
\text { exams }(€)\end{array}$ & $1.0(7.3)$ & $2.4(10.5)$ & $4.0(13.2)$ & 0.0002 & $15.0(32.3)$ & $13.9(29.9)$ & $20.8(36.7)$ & 0.0001 \\
\hline $\begin{array}{l}\text { TOTAL DIRECT } \\
\text { COST }(€)\end{array}$ & $81.2(113.3)$ & $116.9(155.4)$ & $225.3(352.1)$ & $<0.0001$ & $148.7(147.3)$ & $229.9(217.3)$ & $434.4(497.7)$ & $<0.0001$ \\
\hline $\begin{array}{l}\text { Sick leaves (indirect } \\
\text { costs) }(€)\end{array}$ & $4.2(83.0)$ & $197.1(2,125.8)$ & $312.6(2,286.2)$ & 0.0002 & $3.9(56.3)$ & $11.3(109.5)$ & $122.4(410.7)$ & $<0.0001$ \\
\hline TOTAL COST $(€)$ & $85.4(153.5)$ & $314.0(2,160.4)$ & $537.9(2,355.7)$ & $<0.0001$ & $152.6(162.1)$ & $241.2(266.8)$ & $556.8(762.4)$ & $<0.0001$ \\
\hline
\end{tabular}

*The tests were performed to compare controlled, partially controlled and uncontrolled patients.

known. Possible explanations include differences in patient compliance with asthma treatments, as well as environmental and genetic factors. In addition, there may be measurement issues as physicians may vary in their assessment of GINA's criteria.
Indeed, an important study found also great variability in the prevalence of uncontrolled asthma across European countries [10].

In our study, the average total cost per patient over a 3-month period was higher when asthma was poorly

Table 4 Multivariate analyses of asthma related direct costs (€) (3-month observational period)

\begin{tabular}{|c|c|c|c|c|c|}
\hline \multirow{2}{*}{$\begin{array}{l}\text { Country } \\
\text { Direct asthma related costs }\end{array}$} & & \multicolumn{2}{|c|}{ France } & \multicolumn{2}{|c|}{ Spain } \\
\hline & & Estimated Value & $\mathrm{Cl} 95 \%$ & Estimated Value & $\mathrm{Cl} 95 \%$ \\
\hline \multirow[t]{2}{*}{ Level of control measured with GINA } & Partially controlled (vs. controlled) & 14.6 & {$[-15.1 ; 44.3]$} & 1.4 & {$[-40.1 ; 42.9]$} \\
\hline & Uncontrolled (vs. controlled) & $110.9^{*}$ & {$[74.9 ; 146.8]$} & $104.6^{*}$ & {$[58.1 ; 151.1]$} \\
\hline Gender & Men vs. women & -19.5 & {$[-45.6 ; 6.6]$} & $50.9^{*}$ & {$[18.2 ; 83.6]$} \\
\hline \multirow[t]{2}{*}{ Age } & 45-64 years (vs. $\geq 18-44$ years) & $39.2^{*}$ & {$[10.1 ; 68.3]$} & $88.3^{*}$ & {$[51.5 ; 125.1]$} \\
\hline & $\geq 65$ years (vs. $\geq 18$-44years) & $51.3^{*}$ & {$[17.1 ; 85.5]$} & $79.6^{*}$ & {$[35.3 ; 123.9]$} \\
\hline Presence of exacerbation & Yes (vs. None) & $74.6^{*}$ & {$[46.5 ; 102.6]$} & $159.8^{*}$ & {$[122.4 ; 197.2]$} \\
\hline Patient with at least one co-morbidity** & Yes (vs. None) & 26.8 & {$[-2.3 ; 55.9]$} & 11.8 & {$[-26.3 ; 49.8]$} \\
\hline Controller treatment & Yes (vs. None) & $254.3^{*}$ & {$[226.9 ; 281.6]$} & $221.6^{*}$ & {$[184.4 ; 258.7]$} \\
\hline Patient followed by a lung specialist & Yes (vs. None) & $59.7^{*}$ & {$[33.7 ; 85.6]$} & $218.7^{*}$ & {$[181.0 ; 255.3]$} \\
\hline
\end{tabular}

* $\mathrm{p}<0.05$.

** In France, the most frequent co-morbidity was depression and in Spain it was gastroesophageal reflux. 
Table 5 EQ-5D-3L ${ }^{\circledR}$ scores per level of control

\begin{tabular}{|c|c|c|c|c|c|c|}
\hline & & & \multicolumn{4}{|c|}{ Quality of life according to GINA (last 3 months) } \\
\hline & & & Controlled & Partially controlled & Uncontrolled & $\mathbf{p}$ \\
\hline \multirow[t]{4}{*}{ EQ-5D-3L ${ }^{\circledR}$ score } & France & $\mathrm{N}$ & 344 & 307 & 182 & \\
\hline & & Mean (SD) & $0.88(0.18)$ & $0.78(0.23)$ & $0.63(0.28)$ & $<0.0001$ \\
\hline & Spain & N & 436 & 498 & 529 & \\
\hline & & Mean (SD) & $0.89(0.16)$ & $0.82(0.20)$ & $0.69(0.24)$ & $<0.0001$ \\
\hline \multirow[t]{4}{*}{ VAS } & France & $\mathrm{N}$ & 332 & 297 & 171 & \\
\hline & & Mean (SD) & $77.33(15.02)$ & $70.27(16.74)$ & $57.41(18.30)$ & $<0.0001$ \\
\hline & Spain & $\mathrm{N}$ & 435 & 496 & 528 & \\
\hline & & Mean (SD) & $80.00(14.13)$ & $75.13(16.17)$ & $62.81(18.11)$ & $<0.0001$ \\
\hline
\end{tabular}

controlled. Hospitalizations for asthma and emergency room visits associated costs were higher in patients with uncontrolled asthma and they represent a higher percentage of the total direct costs $(16.7 \%$ and $18.6 \%$ of the total direct cost in France and Spain respectively versus $0 \%$ and $0.6 \%$ in patients with controlled asthma).
This result is in line with previous European results $[14,16,21]$.

However, antiasthmatic drugs were the main driver of direct costs in both countries. In addition, the use of controller treatment was associated with the highest direct asthma-related costs regardless of the level of control

Table 6 Multivariate analyses of EQ-5D-3L ${ }^{\circledR}$ utility score (3-month observational period)

\begin{tabular}{|c|c|c|c|c|c|}
\hline \multirow{2}{*}{$\begin{array}{l}\text { Country } \\
\text { EQ-5D-3L }{ }^{\circledR} 3 \text { L utility score }\end{array}$} & & \multicolumn{2}{|c|}{ France } & \multicolumn{2}{|c|}{ Spain } \\
\hline & & $\begin{array}{l}\text { Estimated } \\
\text { Value }\end{array}$ & $\mathrm{Cl} 95 \%$ & $\begin{array}{l}\text { Estimated } \\
\text { Value }\end{array}$ & $\mathrm{Cl} 95 \%$ \\
\hline \multirow[t]{2}{*}{ Level of control measured with GINA } & $\begin{array}{l}\text { Partially controlled (vs. } \\
\text { controlled) }\end{array}$ & $-0.093^{*}$ & {$[-0.128 ;-0.058]$} & $-0.042^{*}$ & {$[-0.068 ;-0.017]$} \\
\hline & Uncontrolled (vs. controlled) & $-0.220^{*}$ & {$[-0.263 ;-0.177]$} & $-0.158^{*}$ & {$[-0.186 ;-0.129]$} \\
\hline Gender & Men vs. women & $0.056^{*}$ & {$[0.019 ; 0.081]$} & $0.052^{*}$ & {$[0.032 ; 0.072]$} \\
\hline \multirow[t]{2}{*}{ Age } & 45-64 years (vs. $\geq 18-44$ years) & $-0.071^{*}$ & {$[-0.105 ;-0.036]$} & $-0.101^{*}$ & {$[-0.123 ;-0.078]$} \\
\hline & $\geq 65$ years (vs. $\geq 18$-44years) & $-0.131^{*}$ & {$[-0.171 ;-0.091]$} & $-0.175^{*}$ & {$[-0.202 ;-0.148]$} \\
\hline Presence of exacerbation & Yes (vs. None) & -0.011 & {$[-0.044 ; 0.024]$} & -0.005 & {$[-0.028 ; 0.017]$} \\
\hline $\begin{array}{l}\text { Patient with at least one co- } \\
\text { morbidity }\end{array}$ & Yes (vs. None) & -0.019 & {$[-0.053 ; 0.014]$} & $-0.028^{*}$ & {$[-0.051 ;-0.004]$} \\
\hline Controller treatment & Yes (vs. None) & -0.025 & {$[-0.056 ; 0.006]$} & 0.009 & {$[-0.012 ; 0.032]$} \\
\hline Patient followed by a lung specialist & Yes (vs. None) & -0.016 & {$[-0.046 ; 0.015]$} & $-0.037^{*}$ & {$[-0.059 ;-0.014]$} \\
\hline VAS Score & & $\begin{array}{l}\text { Estimated } \\
\text { Value }\end{array}$ & Cl $95 \%$ & $\begin{array}{l}\text { Estimated } \\
\text { Value }\end{array}$ & $\mathrm{Cl} 95 \%$ \\
\hline \multirow[t]{2}{*}{ Level of control measured with GINA } & $\begin{array}{l}\text { Partially controlled } \\
\text { (vs. controlled) }\end{array}$ & $-5.777^{*}$ & {$[-8.331 ;-3.223]$} & $-2.762^{*}$ & {$[-4.850 ;-0.675]$} \\
\hline & Uncontrolled (vs. controlled) & $-16.758^{*}$ & {$[-19.959 ;-13.556]$} & $-13.255^{*}$ & {$[-15.609 ;-10.901]$} \\
\hline Gender & Men vs. women & $3.456^{*}$ & {$[1.198 ; 5.714]$} & $2.232^{*}$ & {$[0.577 ; 3.887]$} \\
\hline \multirow[t]{2}{*}{ Age } & 45-64 years(vs. $\geq 18-44$ years) & $-5.966^{*}$ & {$[-8.480 ;-3.453]$} & $-8.492^{*}$ & {$[-10.359 ;-6.625]$} \\
\hline & $\geq 65$ years (vs. $\geq 18$-44years) & $-11.179^{*}$ & {$[-14.140 ;-8.218]$} & $-12.258^{*}$ & {$[-14.507 ;-10.008]$} \\
\hline Presence of exacerbation & Yes (vs. None) & $-2.542^{*}$ & {$[-5.077 ;-0.007]$} & $-2.967^{*}$ & {$[-4.872 ;-1.063]$} \\
\hline $\begin{array}{l}\text { Patient with at least one co- } \\
\text { morbidity }\end{array}$ & Yes (vs. None) & $-3.283^{*}$ & {$[-5.735 ;-0.831]$} & 0.092 & {$[-1.842 ; 2.027]$} \\
\hline Controller treatment & Yes (vs. None) & -0.749 & {$[-3.037 ; 1.539]$} & 1.788 & {$[-0.064 ; 3.642]$} \\
\hline Patient followed by a lung specialist & Yes (vs. None) & -1.721 & {$[-3.955 ; 0.513]$} & $-3.085^{*}$ & {$[-4.981 ;-1.188]$} \\
\hline
\end{tabular}

${ }^{*} p<0.05$. 
and after adjustment for several potentially confounding factors (except in the subgroup of Spanish patients with uncontrolled asthma).

The EUCOAST study presents several limits. First, both the sampling frame and the sampling method used did not ensure the representativeness of the investigators even if their main characteristics were comparable to those of all French and Spanish GPs.

Secondly, as investigators had to recruit several patients (until 5 in Spain) there was a potential within-unit correlation in the data which was not taken into account in the statistical analysis.

Thirdly, due to a possible short term memory bias GPs and patients may have under-reported healthcare consumptions. Therefore, costs may be lower than those found in studies based on claims databases or systematic healthcare data. However, it is difficult to know whether, or to what extent, this might have biased our estimates of the effects associated with level of asthma control. Indeed, the existence of such bias would depend on whether under-reporting of costs was differential according to level of asthma control.

Costs of medications were based on prescription data. As some patients may not have been compliant, our estimates may be over-estimates of the true medicationrelated costs.

The response rate for the EQ-5D-3L ${ }^{\circledR}$ was lower in France as compare to Spain (73\% vs. 97\%). This was likely the consequence of differences in the HRQL data collection method in the two countries. In France, patients were asked to send back their questionnaires to the study center whereas in Spain most patients completed the questionnaire in the physician's office. However, we did not find significant differences between responders and non-responders in their level of asthma control or overall costs.

\section{Conclusion}

Asthma control was significantly associated with costs and health-related quality of life in both France and Spain. Despite differences in health care systems and after adjustment for several potentially confounding factors, in both countries, costs were higher and HRQL lower as level of asthma control decreased.

These results suggest that implementation of measures to improve asthma control may improve patients' quality of life and reduce related costs for National Health Systems and for the society.

\section{Endnotes}

${ }^{a}$ In France: public prices inclusive of tax were used to get the unit cost of drugs; the rates for all medical and paramedical procedures were established from national conventions and from the Common Classification of
Medical Procedures for the year remove one as it is written twice 2010.

${ }^{\mathrm{b}}$ In Spain, the database used for drug costing was that of the Consejo General de Colegios Oficiales de Farmacéuticos (http://www.portalfarma.com). For other resources, costing was carried out using a national Spanish base (Spanish Health costs database eSalud).

\section{Abbreviations \\ AEMPS: Spanish Agency of Medicines and Medical Devices, CCTIRS, Consultative Committee for the data processing in health research; CEIC: Clinical research Ethics Committee; Cl: Confidence interval; CNIL: National commission for the personal data protection COPD, chronic obstructive pulmonary disease, CSD, Cegedim Strategic Data; ECRHS- II: European Community Respiratory Health Survey-II; ESPS: Enquête Santé Protection Sociale; EUCOAST: EUropean COst of ASthma Treatment; FEV1: Force expiratory volume in one second; GERD: Gastroesophageal reflux disease; GINA: Global initiative for asthma; GPs: General practitioners; HRQL: Health related quality of life; QoL: Quality of life; SD: Standard deviation; SRAP: Sociedad de Respiratorio de Atención Primaria; VAS: Visual analog scale.}

\section{Competing interests}

Doz M, Robert J and Detournay B are consultants for CEMKA-EVAL, a company providing consultancy services for most pharmaceutical companies and public institutions involved in health care in France. Chouaid $C$ has received consulting fees or honoraria from Novartis, Boehringer Ingelheim, AstraZeneca and GlaxoSmithKline. Calvo E has worked as national coordinator for primary care in international clinical trials sponsored by Astra Zeneca and has been principal or secondary investigator in national studies conducted by Astra Zeneca, Boehringher, MSD, GlaxoSmithKline and Abbott. He has also written papers or given courses and conferences sponsored by Boehringher, Pfizer, AstraZeneca, GlaxoSmithKline, Chiesi, Merck and Almirall. He has participated in advisory committees for GlaxoSmithKline, Nycomed and Novartis. Com-Ruelle $L$ received consulting fees or honoraria from GlaxoSmithKline as an expert of the study scientific committee. Brosa M is consultant for Oblikue, a company providing consultancy services for most pharmaceutical companies and public institutions involved in health care in Spain. Decuypère $L$ and Pribil $C$ are employed at GlaxoSmithKline France. Huerta A is employed at GlaxoSmithKline Spain.

\section{Authors' contribution}

DM coordinated the data collection and wrote the manuscript. CC, CRL, CE, $\mathrm{BM}$ and $\mathrm{DL}$ participated in the interpretation of data, were involved in drafting the manuscript and revised it critically for important intellectual content. RJ performed all statistical analysis. PC and HA participated in study conception and interpretation of data and revised the manuscript. DB participated to conception and design, acquisition and interpretation of data, was involved in drafting the manuscript and revised it critically for important intellectual content. All authors have read and approved the final manuscript.

\section{Acknowledgements}

Financial support for this study has been provided by GlaxoSmithKline, Access to Medicines Centre of Excellence, UK.

\section{Author details}

${ }^{1}$ Cemka-Eval, 43 Boulevard du Maréchal Joffre, Bourg-la-Reine F-92340, France. ${ }^{2}$ APHP, Hôpital Saint-Antoine, Service de Pneumologie, 184 rue du Fbg Saint-Antoine, Paris F-75571 cedex 12, France. ${ }^{3}$ Institut de recherche et documentation en économie de la santé (IRDES), 10 rue Vauvenargues, Paris F-75018, France. ${ }^{4}$ Centro de Salud Universitario Pozuelo Estación, Madrid, Spain. ${ }^{5}$ Oblikue Consulting, C/ Josep Irla i Bosh, 5-7, 1a planta S-08034, Barcelona, Spain. ${ }^{6}$ GlaxoSmithKline, 100 Route de Versailles, Marly-le-Roi cedex, France. ${ }^{7}$ GlaxoSmithKline, Parque Tecnologico de Madrid, Severo ochoa 2, S-28760 Tres Cantos, Madrid, Spain.

Received: 21 June 2012 Accepted: 19 February 2013

Published: 22 March 2013 


\section{References}

1. Global Strategy for Asthma Management and Prevention, Global Initiative for Asthma (GINA) 2009. [Report accessed on www.ginasthma.org, in September 2011]

2. Masoli M, Fabian D, Holt S, Beasley R, Medical Research Institute of New Zealand, Wellington, New Zealand University of Southampton Southampton, United Kingdom: The Global Burden of Asthma Report, Global Initiative for Asthma (GINA). http://www.ginasthma.org/local/uploads/ files/GINABurdenReport_1.pdf.

3. Afrite A, Allonier C, Com-Ruelle L, Le Guen N: L'asthme en France en 2006: prévalence et contrôle des symptômes. Issues Health Econ (Questions d'économie de la santé) 2008, 138:1-8.

4. Urrutia I, Aguirre U, Sunyer J, Plana E, Muniozguren N, Martinez-Moratalla J, Payo F, Maldonado JA, Anto JM, Estudio de Salud Respiratoria de la Comunidad Europea: Changes in the prevalence of asthma in the Spanish cohort of the European Community Respiratory Health Survey (ECRHS-II). Arch Bronconeumol 2007, 43(8):425-430.

5. Kroegel $\mathrm{C}$, Wirtz $\mathrm{H}$ : History of guidelines for the diagnosis and management of asthma: from opinion to control. Drugs 2009, 69(9):1189-1204

6. Juniper EF, O'Byrne PM, Guyatt GH, Ferrie PJ, King DR: Development and validation of a questionnaire to measure asthma control. Eur Respir J 1999, 14(4):902-907.

7. Juniper EF, O'Byrne PM, Ferrie PJ, King DR, Roberts JN: Measuring asthma control: clinic questionnaire or daily diary? Am J Respir Crit Care Med 2000, 162(4 Pt 1):1330-1334.

8. Schatz M, Sorkness CA, Li JT, Marcus P, Murray JJ, Nathan RA, Kosinski M, Pendergraft TB, Jhingran P: Asthma Control Test: reliability, validity, and responsiveness in patients not previously followed by asthma specialists. J Allergy Clin Immunol 2006, 117(3):549-556.

9. Nathan RA, Sorkness CA, Kosinski M, Schatz M, Li JT, Marcus P, Murray JJ, Pendergraft TB: Development of the asthma control test: a survey for assessing asthma control. J Allergy Clin Immunol 2004, 113(1):59-65.

10. Cazzoletti L, Marcon A, Janson C, Corsico A, Jarvis D, Pin I, Accordini S, Almar E, Bugiani M, Carolei A, Cerveri I, Duran-Tauleria E, Gislason D, Gulsvik A, Jõgi R, Marinoni A, Martínez-Moratalla J, Vermeire P, de Marco R, Therapy and Health Economics Group of the European Community Respiratory Health Survey: Asthma control in Europe: a real-world evaluation based on an international population-based study. J Allergy Clin Immunol 2007, 120(6):1360-1367.

11. Demoly P, Gueron B, Annunziata K, Adamek L, Walters R: Update on asthma control in five European countries: results of a 2008 survey. Eur Respir Rev 2010, 19(116):150-157.

12. Fueyo A, Ruiz MA, Ancochea J, Guilera M, Badia X, ESCASE Group: Asthma control in Spain. Do season and treatment pattern matter? The ESCASE study. Respir Med 2007, 101(5):919-924.

13. Godard P, Chanez P, Siraudin L, Nicoloyannis N, Duru G: Costs of asthma are correlated with severity: a 1-yr prospective study. Eur Respir J 2002, 19(1):61-67.

14. Com-Ruelle L, Grandfils N, Midy F, Sitta R: Determinants of the medical cost of asthma in the lle-de-France area. Issues Health Econ (Questions d'économie de la santé) 2002, 58:1-4.

15. Nieto A, Álvarez-Cuesta E, Boquete M, Mazón A, De la Torre F: The cost of asthma treatment in Spain and rationalizing the expense. I Investig Allergol Clin Immunol 2001, 11(3):139-148.

16. Com-Ruelle L, Da Poian MT, Le Guen N: Asthma Patients' Ambulatory Care Expenditures in 2006. Issues Health Econ (Questions d'économie de la santé) 2010, 152:1-8

17. Australian Centre for Asthma Monitoring 2004: Measuring the impact of asthma on quality of life in the Australian population. Cat. no. ACM 3. Canberra: AlHW. http://www.nationalasthma.org.au/uploads/publication/ asthma-quality-of-life.pdf.

18. Voll-Aanerud M, Eagan TM, Plana E, Omenaas ER, Bakke PS, Svanes C, Siroux $V$, Pin I, Antó JM, Leynaert B: Respiratory symptoms in adults are related to impaired quality of life, regardless of asthma and COPD: results from the European community respiratory health survey. Health Qual Life Outcomes 2010, 8:107.

19. Dean BB, Calimlim BM, Kindermann SL, Khandker RK, Tinkelman D: The impact of uncontrolled asthma on absenteeism and health-related quality of life. J Asthma 2009, 46(9):861-866.
20. Allegra L, Cremonesi G, Girbino G, Ingrassia E, Marsico S, Nicolini G, Terzano C, PRISMA (Prospective Study on asthma control) Study Group: Real-life prospective study on asthma control in Italy: cross-sectional phase results. Respir Med 2012, 106(2):205-214.

21. Guilbert TW, Garris C, Jhingran P, Bonafede M, Tomaszewski KI, Bonus T, Hahn RM, Schatz M: Asthma that is not well-controlled is associated with increased healthcare utilization and decreased quality of life. J Asthma 2011, 48(2):126-132.

22. Godard P, Huas D, Sohier B, Pribil C, Boucot I: ER'Asthme, contrôle de l'asthme chez 16580 patients suivis en médecine générale. Presse Med 2005, 34:1351-1357.

23. Rabin R, de Charro F: EQ-5D: a measure of health status from the EuroQol Group. Ann Med 2001, 33(5):337-343.

24. Pickard AS, Wilke C, Jung E, Patel S, Stavem K, Lee TA: Use of a preferencebased measure of health (EQ-5D) in COPD and asthma. Respir Med 2008, 102(4):519-536.

25. Szende A, Leidy NK, Stahl E, Svensson K: Estimating health utilities in patients with asthma and COPD: evidence on the performance of EQ-5D and SF-6D. Qual Life Res 2009, 18(2):267-272.

26. Chevalier J, de Pouvourville G: Valuing EQ-5D using Time Trade-Off in France. Eur J Health Econ 2011. Epub ahead of print.

27. Badía X, Roset M, Montserrat S, Herdman M, Segura A: La versión española del EuroQol: descripción y aplicaciones. Med Clin (Barc) 1999, 112(1):79-85.

28. Global Strategy for Asthma Management and Prevention, Global Initiative for Asthma (GINA) 2010. [Report accessed on www.ginasthma.org, in September 2011]

29. Didier A, Godard P, Vervloet D, Pribil C, El Azzi G, Serrier P, Dumur JP, Salmeron S: Predictive factors of asthma control in clinical practice in France [abstract]. Berlin: Communication at the ERS Congress; 2008:E227.

30. Díez Jde M, Barcina C, Muñoz M, Leal M: Control of persistent asthma in Spain: associated factors. J Asthma 2008, 45(9):740-746.

doi:10.1186/1471-2466-13-15

Cite this article as: Doz et al.: The association between asthma control, health care costs, and quality of life in France and Spain. BMC Pulmonary Medicine 2013 13:15.

\section{Submit your next manuscript to BioMed Central and take full advantage of:}

- Convenient online submission

- Thorough peer review

- No space constraints or color figure charges

- Immediate publication on acceptance

- Inclusion in PubMed, CAS, Scopus and Google Scholar

- Research which is freely available for redistribution 